\title{
Efektifitas Kemasan dan Suhu Ruang Simpan terhadap Daya Simpan Benih Kedelai (Glycine max (L.) Meirril)
}

\author{
DOI 10.18196/pt.2015.033.1-7
}

\section{Marlinda Dwi Purwanti}

Diamond Seed Indonesia, Jl. Raya Wonosari, Rt. 01/Rw. 01, Grogol, Kediri, Jawa Timur, Indonesia, e-mail:sarjiyah@umy.ac.id

\begin{abstract}
ABSTRAK
Penelitian ini bertujuan untuk mendapatkan macam kemasan dan suhu ruang simpan yang tepat pada penyimpanan benih kedelai. Metode penelitian yang digunakan yaitu percobaan Laboratorium, dengan rancangan factorial 5 x 3, disusun dalam Rancangan Acak Lengkap (RAL). Faktor pertama adalah macam kemasan dengan 5 aras yaitu plastic PP (Poly Propylene) divacum, Plastik PP (Poly Propylene) tanpa vacum, plastic PE (Poly Ethylene) divacum, plastic PE (Poly Ethilene) tanpa vacum, dan kontrol (tanpa pengemas). Faktor kedua adalah suhu ruang simpan dengan 3 aras yaitu ruang kamar (27-29 C), ruang AC (17-19 $\left.{ }^{\circ} \mathrm{C}\right)$ dan Cooler $\left(7^{\circ} \mathrm{C}\right)$. Hasil penelitian menuniukkan bahwa penyimpanan benih kedelai pada suhu ruang kamar (27-29 으) dengan kemasan plastik Poly Ethylene (PE) dan Poly Propylene (PP) divacum maupun tanpa vacum dapat mempertahankan mutu benih kedelai selama 4 bulan disimpan. Sedangkan penyimpanan benih kedelai pada suhu ruang AC (17-19 $\left.{ }^{\circ} \mathrm{C}\right)$ dan suhu ruang Cooler $\left(7^{\circ} \mathrm{C}\right)$ dengan kemasan plastik PE atau PP divacum atau tanpa vacum, bahkan tidak dikemas dapat mempertahankan kualitas benih kedelai selama 4 bulan disimpan.

Kata kunci: Benih kedelai, Kemasan, Suhu ruang simpan
\end{abstract}

\begin{abstract}
This study aims to determine the best of packaging types and storage temperature for soybean seeds. The research was conducted in laboratory using a $5 \times 3$ factorial design arranged in a completely randomized design (CRD). The first factor was the types of packaging namely PP plastic (Poly Prophylene) vaccuum, PP plastic (Poly Prophylene) without vaccuum, PE plastic (Poly Ethylene) vaccuum, PE plastic (Poly Ethylene) without vaccuum, and control (without packaging). The second factor was the temperature of storage room, i.e. room temperature (27-29 $\left.{ }^{\circ} \mathrm{C}\right)$, air conditioned room (17-19 $\mathrm{C}$ ) and Cooler room $\left(7^{\circ} \mathrm{C}\right)$. Each treatment was replicated 4 times. The results showed that the best packaging type for storing seed at temperature $\left(27\right.$-29 $\left.{ }^{\circ} \mathrm{C}\right)$ PP plastic \& PE plastic with and without vaccuum. However, the soybean seed storaged in air-conditioned room (17-19 ${ }^{\circ} \mathrm{C}$ ) and Cooler room temperature (7 $\left.{ }^{\circ} \mathrm{C}\right)$ using the vaccuum, non vaccuum, and withot packaging could maintain the quality of soybead seed for 4 months.

Keywords: Soybean seeds, Packaging types, Storage temperature
\end{abstract}

\section{PENDAHULUAN}

Kedelai merupakan salah satu palawija yang banyak dikonsumsi oleh masyarakat karena nilai gizinya yang tinggi (Tatipata et. al. 2004). Kedelai sering dimanfaatkan sebagai bahan baku untuk berbagai produk pangan, baik dalam bentuk segar, makanan fermentasi seperti susu, tahu, tempe, kecap, dan tauge maupun dalam bentuk kering. Kedelai tidak hanya merupakan bahan pangan, tetapi juga berguna untuk obat berbagai penyakit dan gangguan pada tubuh (Somaatmadja, 1993). Menurut Pitojo (2003), kedelai diyakini dapat mencegah penumpukan kolesterol di dalam tubuh, mencegah timbulnya penyakit jantung koroner dan kanker, serta menghindarkan gangguan kelenjar prostat. Kedelai juga dapat mengurangi risiko terjadinya osteoporosis dan kepikunan.

Kebutuhan kedelai nasional tahun 2010 masih defisit hingga 700 ribu ton dibandingkan tahun sebelumnya. Wakil Menteri Pertanian, Bayu Khrisnamurti mengatakan, produksi kedelai nasional tahun lalu turun menjadi 1 juta ton, untuk memenuhi kebutuhan konsumsi kedelai tahun lalu, yang mencapai 1,7 juta ton, pemerintah mengimpornya dari luar negeri. Impor dilakukan guna memenuhi kebutuhan dalam negeri. (Anonim, 2011).

Hasil rerata kedelai nasional 1,2 ton per hektar, sedangkan hasil rerata kedelai dunia saat ini sudah mencapai 1,9 ton per hektar. Ini merupak- 
an peluang sekaligus sebagai tantangan bagi para petani Indonesia untuk meningkatkan produksi kedelai dalam negeri. Menurut Purwanti (2004), salah satu faktor pembatas produksi kedelai di daerah tropis adalah masih rendahnya pemakaian benih bermutu tinggi oleh petani. Hal tersebut antara lain disebabkan cepatnya kemunduran benih selama penyimpanan, sehingga sulit untuk menyediakan benih berkualitas tinggi. Penyimpanan benih merupakan suatu usaha untuk mempertahankan mutu benih sampai benih tersebut ditanam oleh petani. Penyimpanan benih di daerah tropis sering mengalami kendala terutama karena masalah kelembaban yang tinggi dan fluktuasi suhu. Benih bersifat higroskopis dan kadar airnya selalu berkeseimbangan dengan kelembaban nisbi di sekitarnya. Pemilihan jenis kemasan yang baik harus disesuaikan dengan tipe benih, suhu dan $\mathrm{RH}$ ruang simpan, kadar air awal, lama simpan dan tujuan akhir penyimpanan.Kemunduran benih kedelai selama penyimpanan lebih cepat berlangsung dibandingkan dengan benih tanaman lain dengan kehilangan vigor benih yang cepat yang menyebabkan penurunan perkecambahan benih, sehingga benih kedelai yang akan ditanam harus dikemas dan disimpan dalam lingkungan yang menguntungkan (suhu rendah), agar kualitas benih tetap tinggi sampai akhir penyimpanan (Egli dan Krony, 1996 cit. Viera et. al., 2001 dalam Purwanti 2004).

Tujuan dari penelitian ini adalah untuk mendapatkan macam kemasan dan ruang simpan yang tepat untuk penyimpanan benih kedelai.

\section{BAHAN DAN METODE}

Penelitian dilakukan dengan metode percobaan Laboratorium, dengan rancangan faktorial 5x3, disusun dalam Rancangan Acak Lengkap
(RAL). Faktor pertama adalah macam kemasan dengan 5 aras yaitu Plastik PP (Poly Propylene) divacum, Plastik PP (Poly Propylene) tanpa vacum, plastik PE (Poly Ethylene) divacum, plastik PE (Poly Ethylene) tanpa vacum dan tanpa pengemas (kontrol). Faktor kedua adalah kondisi suhu ruang simpan dengan 3 aras yaitu ruang kamar, ruang AC, dan Cooler, sehingga terdapat 15 perlakuan. Tiap perlakuan diulang 4 kali sehingga diperoleh 60 unit percobaan. Tiap unit percobaan terdiri atas 50 gram benih kedelai, sehingga total benih yang dibutuhkan adalah 50 gram $\mathrm{x}$ $60=3000$ gram $(3 \mathrm{~kg}$ ) benih kedelai. Parameter yang diamati dalam penelitian meliputi kadar air, daya kecambah, index vigor, koefisiensi pekecambahan (CG), tinggi dan berat kering tanaman umur 2 minggu. Data hasil pengamatan dianalisis dengan sidik ragam jenjang nyata 5\%. Bila ada perbedaan nyata antar perlakuan dilakukan Uji Jarak Ganda Duncan atau Duncan Multiple Range (DMRT). Hasil analisis dilengkapi dengan penielasan deskripsi.

\section{HASIL DAN PEMBAHASAN}

Parameter yang diamati dalam penelitian meliputi kadar air, daya kecambah, index vigor, koefisiensi pekecambahan (CG), tinggi dan berat kering tanaman umur 2 minggu.

Tabel 1. Hasil pengujian mutu benih sebelum disimpan

\begin{tabular}{ccc}
\hline No. & Parameter & Hasil \\
\hline 1. & Kadar Air & $10.50 \%$ \\
2. & Daya Kecambah & $96.25 \%$ \\
3. & Index Vigor & $13.80 \%$ \\
4. & Koefisiensi pekecambahan (CG) & $35.09 \%$ \\
5. & Tinggi Tanaman & $16.86 \mathrm{~cm}$ \\
6. & Berat Kering & $3.44 \mathrm{~g}$ \\
\hline
\end{tabular}

Hasil Pengujian Setelah Disimpan

Kadar Air

Dari hasil analisis varian kadar air benih diketahui bahwa ada interaksi antara jenis kemasan 
dan suhu ruang simpan (Tabel 2). Macam kemasan dan suhu memberi pengaruh nyata terhadap kadar air benih setelah disimpan selama empat bulan. Penggunaan kemasan plastik Poly Ethylene, Poly Propylene tanpa maupun divacum pada suhu ruang kamar, ruang AC dan Cooler, kadar air benih dapat dipertahankan tidak meningkat atau melebihi 10,5\% (kadar air benih sebelum disimpan) selama empat bulan disimpan, demikian pula tanpa pengemas pada ruang AC dan Cooler, sedangkan tanpa pengemas pada suhu kamar terjadi peningkatan kadar air secara signifikan hingga mencapai 12, 08 (Tabel 2). Hal ini disebabkan karena benih yang dikemas tidak terpengaruh oleh kondisi ruang simpan, sedangkan benih yang tidak dikemas akan dipengaruhi oleh kondisi ruang simpan sehingga pada suhu kamar dengan kelembaban yang relatif tinggi kadar aiar akan meningkat karena benih bersifat higroskopis. Perubahan kadar air selama penyimpanan dapat dilihat pada Gambar 1, 2, dan 3.

Tabel 2. Rerata kadar air benih setelah disimpan selama 4 bulan (\%)

\begin{tabular}{|c|c|c|c|c|c|c|}
\hline \multirow{2}{*}{$\begin{array}{c}\text { Perlakuan } \\
\text { (R.Simpan) }\end{array}$} & \multicolumn{5}{|c|}{ Kemasan } & \multirow[b]{2}{*}{ Rerata } \\
\hline & $\begin{array}{c}P E \\
\text { Vacuum }\end{array}$ & $\begin{array}{l}\text { PE Non } \\
\text { Vacuum }\end{array}$ & $\begin{array}{c}\text { PP } \\
\text { Vacuum }\end{array}$ & $\begin{array}{l}\text { PP Non } \\
\text { Vacuum }\end{array}$ & $\begin{array}{c}\text { Tanpa } \\
\text { Pengemas }\end{array}$ & \\
\hline $27-29^{\circ} \mathrm{C}$ & $10.48 b$ & $10.20 \mathrm{bcd}$ & $10.08 \mathrm{bcd}$ & $10.28 \mathrm{bcd}$ & $12.08 \mathrm{a}$ & 10.62 \\
\hline $17-19^{\circ} \mathrm{C}$ & 9.85 cde & $10.10 \mathrm{bcd}$ & 9.78 de & $9.38 \mathrm{e}$ & $10.18 \mathrm{bcd}$ & 9.86 \\
\hline $7^{\circ} \mathrm{C}$ & $10.35 b c$ & $10.43 \mathrm{~b}$ & 9.85 cde & $10.23 \mathrm{bcd}$ & 9.85 cde & 10.14 \\
\hline Rerata & 10.22 & 10.24 & 9.90 & 9.95 & 10.70 & $(+)$ \\
\hline \multicolumn{7}{|c|}{ 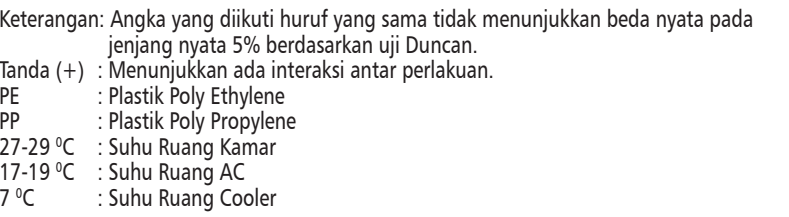 } \\
\hline
\end{tabular}

Dari hasil analisis varian kadar air benih diketahui bahwa ada interaksi antara jenis kemasan dan suhu ruang simpan (Tabel 2). Macam kemasan dan suhu memberi pengaruh nyata terhadap kadar air benih setelah disimpan selama empat bulan. Penggunaan kemasan plastik Poly Ethylene,
Poly Propylene tanpa maupun divacum pada suhu ruang kamar, ruang AC dan Cooler, kadar air benih dapat dipertahankan tidak meningkat atau melebihi 10,5 \% (kadar air benih sebelum disimpan) selama empat bulan disimpan, demikian pula tanpa pengemas pada ruang AC dan Cooler, sedangkan tanpa pengemas pada suhu kamar terjadi peningkatan kadar air secara signifikan hingga mencapai 12, 08 (Tabel 2). Hal ini disebabkan karena benih yang dikemas tidak terpengaruh oleh kondisi ruang simpan, sedangkan benih yang tidak dikemas akan dipengaruhi oleh kondisi ruang simpan sehingga pada suhu kamar dengan kelembaban yang relatif tinggi kadar aiar akan meningkat karena benih bersifat higroskopis. Perubahan kadar air selama penyimpanan dapat dilihat pada Gambar 1, 2, dan 3.

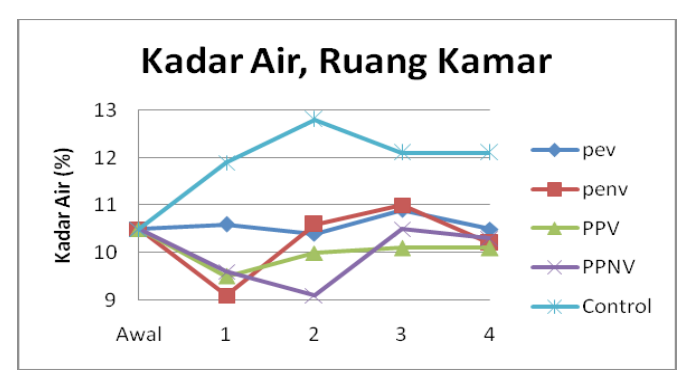

Gambar 1. Kadar air ruang kamar

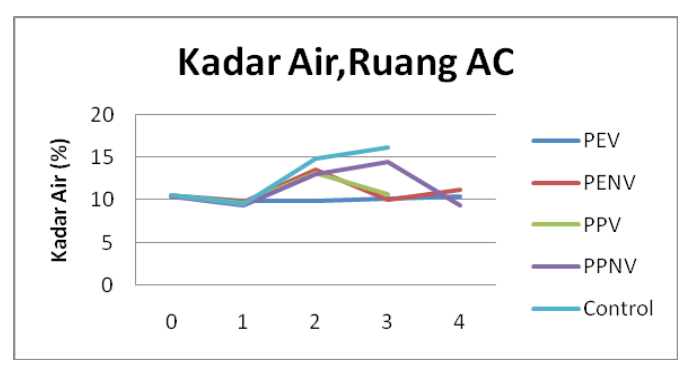

Gambar 2. Kadar air ruang AC

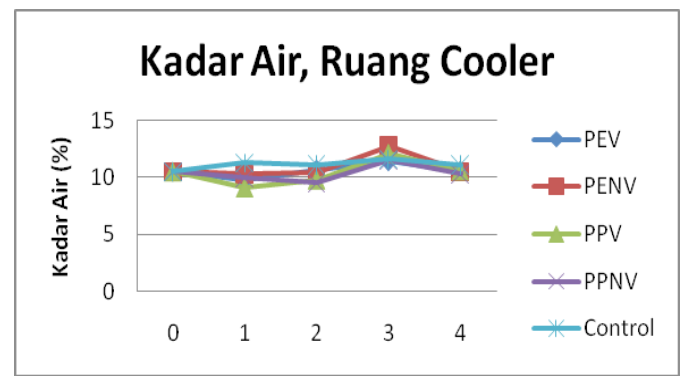

Gambar 3. Kadar air ruang cooler 
Pengaruh ruang simpan pada suhu kamar $( \pm$ 27-29 ${ }^{\circ} \mathrm{C}$ ) dengan macam kemasan terhadap kadar air menunjukkan bahwa plastik Poly Ethylene maupun Poly Propylene vacuum maupun tanpa vacuum terjadi perubahan (fluktuatif) setiap bulannya namun tidak lebih 10,5 (kadar air awal), sedangkan pada pelakuan kontrol cenderung selalu mengalami peningkatan. Demikian pula pada ruang $\mathrm{AC}\left( \pm 17-19^{\circ} \mathrm{C}\right)$ juga terjadi fluktuasi, namun samapai dengan 4 bulan setelah disimpan kadar air tidak lebih dari 10,5 dengan smua jenis kemasan bahkan tidak dikemas sekalipun. Sedangkan pada ruang simpan Cooler $\left(7^{\circ} \mathrm{C}\right)$ dengan berbagai macam kemasan terhadap kadar air menunjukkan bahwa plastik Poly Ethylene maupun Poly Propylene vacuum maupun tanpa vacuum tidak terjadi beda secara signifikan pada peubahan kadar air (relatif stabil), sampai dengan 4 bulan setelah disimpan kadar air masih dapat dipertahankan.

Daya Kecambah (\%)

Tabel 3. Rerata daya kecambah benih setelah disimpan selama 4 bulan

\begin{tabular}{ccccccc}
\hline \multirow{5}{*}{$\begin{array}{c}\text { Perlakuan } \\
\text { (R.Simpan) }\end{array}$} & \multicolumn{5}{c}{ Kemasan } & \\
\cline { 2 - 5 } & $\begin{array}{c}\text { PE } \\
\text { Vacuum }\end{array}$ & $\begin{array}{c}\text { PE Non } \\
\text { Vacuum }\end{array}$ & $\begin{array}{c}\text { PP } \\
\text { Vacuum }\end{array}$ & $\begin{array}{c}\text { PP Non } \\
\text { Vacuum }\end{array}$ & $\begin{array}{c}\text { Tanpa } \\
\text { Pengemas }\end{array}$ & Rerata \\
\hline $27-29{ }^{\circ} \mathrm{C}$ & $98.13 \mathrm{a}$ & $89.38 \mathrm{a}$ & $88.76 \mathrm{a}$ & $95.00 \mathrm{a}$ & $48.76 \mathrm{~b}$ & 84.00 \\
$17-19{ }^{\circ} \mathrm{C}$ & $95.00 \mathrm{a}$ & $92.51 \mathrm{a}$ & $90.00 \mathrm{a}$ & $92.51 \mathrm{a}$ & $92.51 \mathrm{a}$ & 92.51 \\
$7{ }^{\circ} \mathrm{C}$ & $93.75 \mathrm{a}$ & $95.00 \mathrm{a}$ & $93.76 \mathrm{a}$ & $95.63 \mathrm{a}$ & $92.51 \mathrm{a}$ & 94.13 \\
Rerata & 95.63 & 92.30 & 90.84 & 94.38 & 77.92 & $(+)$ \\
\hline
\end{tabular}

Keterangan: Angka yang diikuti huruf yang sama tidak menunjukkan beda nyata pada jenjang nyata $5 \%$ berdasarkan uji Duncan.

Tanda (+) : Menunjukkan ada interaksi antar perlakuan.

PE : Plastik Poly Ethylene

$\begin{array}{ll}\mathrm{PP} & \text { : Plastik Poly Propylene } \\ 27-29^{\circ} \mathrm{C} & \text { : Suhu Ruang Kamar }\end{array}$

$17-19^{\circ} \mathrm{C}$ : Suhu Ruang AC

$7{ }^{\circ} \mathrm{C} \quad$ : Suhu Ruang Cooler

Dari hasil analisis daya kecambah benih setelah empat bulan disimpan diketahui bahwa ada interaksi antara kemasan dan suhu ruang simpan. Dari seluruh kombinasi perlakuan macam kemasan dengan suhu ruang simpan menunjukkan bahwa daya kecambah benih setelah 4 bulan disimpan masih tinggi dan memenuhi standar mutu benih kedelai (80 \%) kecuali pada perlakuan benih kedelai tidak dikemas dan disimpan pada ruang kamar (Tabel 3). Hal ini berkaitan dengan kadar air benih setelah 4 bulan disimpan pada perlakuan tersebut meningkat menjadi 12,08 \%, sehingga laju respirasi meningkat, cadangan makanan dalam benih menurun dan daya kecambahnya menjadi rendah. Hasil pengujian daya kecambah selama 4 bulan dapat dilihat pada Gambar 4, 5 dan 6 .

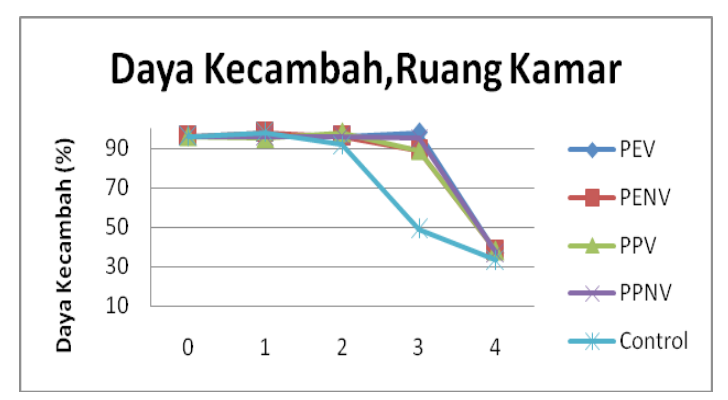

Gambar 4. Daya Kecambah Ruang Kamar

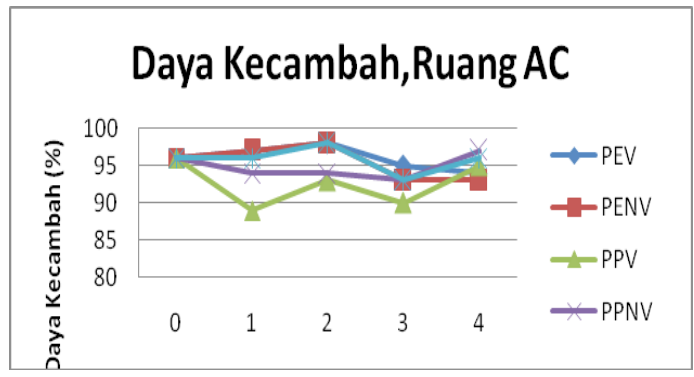

Gambar 5. Daya Kecambah Ruang AC

\section{Daya Kecambah, Ruang Cooler}

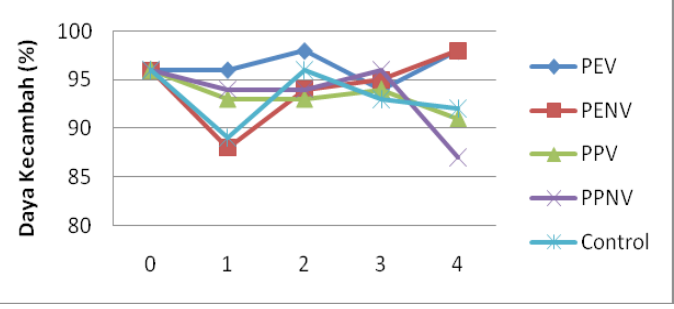

Gambar 6. Daya Kecambah Ruang Cooler 
Pada suhu ruang kamar dengan kemasan plastik PE maupun PP divacum maupun tanpa vacum daya kecambah benih pada umur simpan 1 sampai dengan 4 bulan relatif stabil (penurunan sangat kecil), sedangkan penyimpanan dengan tanpa dikemas daya kecambah terus mengalami penurunan dari bulan ke bulan sampai dengan 48,76 (Gambar 4). Pada gambar 5 dan 6 dapat dilihat bahwa daya kecambah benih yang disimpan di ruang AC dan Cooler dengan kemasan plastik PE maupun PP divacum maupun tanpa vacum, dan tanpa dikemas mengalami fluktuasi namun sampai dengan 4 bulan disimpan daya kecambahnya masih lebih dari $80 \%$, atau masih memenuhi standar mutu benih yang baik dan bisa digunakan sebagai bahan tanam.

\section{Index Vigor}

Tabel 4. Rerata Index Vigor benih setelah disimpan selama 4 bulan

\begin{tabular}{|c|c|c|c|c|c|c|}
\hline \multirow{2}{*}{$\begin{array}{c}\text { Perlakuan } \\
\text { (R.Simpan) }\end{array}$} & \multicolumn{5}{|c|}{ Kemasan } & \multirow[b]{2}{*}{ Rerata } \\
\hline & $\begin{array}{c}P E \\
\text { Vacuum }\end{array}$ & $\begin{array}{l}\text { PE Non } \\
\text { Vacuum }\end{array}$ & $\begin{array}{c}\text { PP } \\
\text { Vacuum }\end{array}$ & $\begin{array}{l}\text { PP Non } \\
\text { Vacuum }\end{array}$ & $\begin{array}{c}\text { Tanpa } \\
\text { Pengemas }\end{array}$ & \\
\hline $27-29^{\circ} \mathrm{C}$ & $12.58 \mathrm{a}$ & $11.28 \mathrm{a}$ & $11.13 \mathrm{a}$ & $12.16 \mathrm{a}$ & $5.35 \mathrm{~b}$ & 10.50 \\
\hline $17-19^{\circ} \mathrm{C}$ & $12.48 \mathrm{a}$ & $11.51 \mathrm{a}$ & $11.63 \mathrm{a}$ & $11.75 \mathrm{a}$ & $11.83 \mathrm{a}$ & 11.84 \\
\hline $7^{\circ} \mathrm{C}$ & $12.25 \mathrm{a}$ & $12.28 \mathrm{a}$ & $11.75 \mathrm{a}$ & $12.28 \mathrm{a}$ & $11.68 \mathrm{a}$ & 12.05 \\
\hline Rerata & 12.44 & 11.69 & 11.50 & 12.06 & 9.62 & $(+)$ \\
\hline \multicolumn{7}{|c|}{ 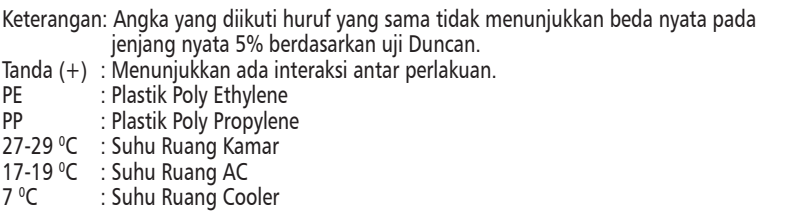 } \\
\hline
\end{tabular}

Dari hasil pengujian benih sebelum disimpan dan setelah dilakukan penyimpanan selama 4 bulan, index vigor benih menunjukkan terjadinya penurunan walaupun tidak terlalu besar. Berdasarkan hasil analisis index vigor benih setelah 4 bulan disimpan menunjukkan ada interaksi antara macam kemasan dengan suhu ruang simpan terhadap index vigor benih, seperti dapat dilihat pada tabel 4 . Benih yang disimpan dalam ruang
AC maupun Cooler dengan dikemas menggunakan plastik PP maupun PE divacum maupun tidak divacum, serta tidak dikemas indek vigornya masih relatif tinggi, demikian juga penyimpanan pada ruang kamar dengan kemasan PP maupun PE divacum maupun tidak divacum. Sedangkan benih yang disimpan pada ruang kamar dengan tidak dikemas indek vigornya nyata lebih rendah. Hal ini disebabkan benih yang tidak dikemas dan disimpan pada ruang kamar akan sangat dipengaruhi oleh kondisi udara dalam ruang kamar (suhu dan kelembaban cenderung tinggi) sehingga kadar air meningkat, laju respirasi benih meningkat yang mengakibatkan cadangan makanan dalam benih menurun sehingga indek vigorpun rendah. Dari gambar 7 - 9 dapat dilihat bahwa vigor benih dari waktu ke waktu mengalami penurunan karena berkurangnya cadangan makanan dalam benih untuk respirasi embrio, sampai dengan 4 bulan setelah disimpan indek vigor menurun secara signifikan pada perlakuan benih tidak dikemas dan disimpan dalam ruang kamar $(5,35)$, sedangkan penurunan indek vigor dengan kemasan tidak terlalu signifikan berkisar 11,13 - 12,58 (indek vigor awal 13,50).

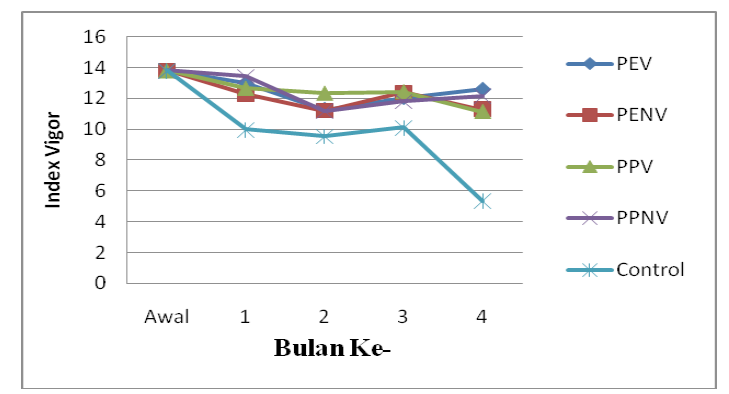

Gambar 7. Index Vigor Ruang Kamar 


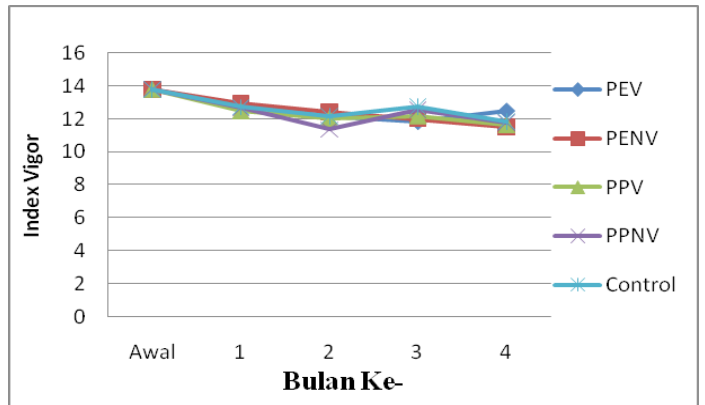

Gambar 8. Index Vigor Ruang AC

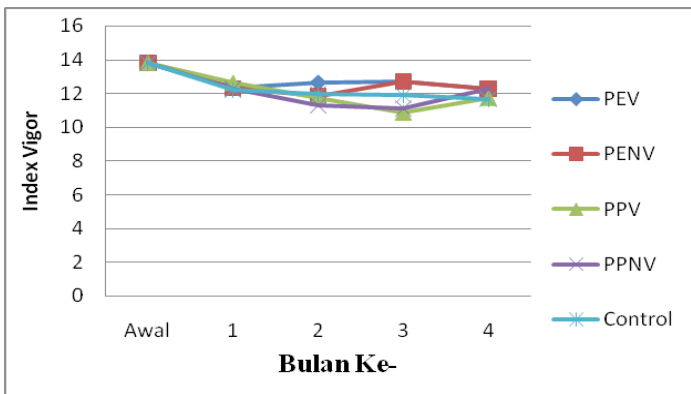

Gambar 9. Index Vigor Ruang Cooler

\section{Koefisiensi Perkecambahan (CG)}

Tabel 5. Rerata koefisiensi pekecambahan (CG) setelah benih disimpan selama 4 bulan

\begin{tabular}{ccccccc}
\hline \multirow{2}{*}{$\begin{array}{c}\text { Perlakuan } \\
\text { (R.Simpan) }\end{array}$} & \multicolumn{5}{c}{ Kemasan } & \\
\cline { 2 - 5 } & $\begin{array}{c}\text { PE } \\
\text { Vacuum }\end{array}$ & $\begin{array}{c}\text { PE Non } \\
\text { Vacuum }\end{array}$ & $\begin{array}{c}\text { PP } \\
\text { Vacuum }\end{array}$ & $\begin{array}{c}\text { PP Non } \\
\text { Vacuum }\end{array}$ & $\begin{array}{c}\text { Tanpa } \\
\text { Pengemas }\end{array}$ & Rerata \\
\hline $27-29^{\circ} \mathrm{C}$ & $31.06 \mathrm{a}$ & $30.86 \mathrm{a}$ & $29.63 \mathrm{a}$ & $30.93 \mathrm{a}$ & $24.73 \mathrm{~b}$ & 29.44 \\
$17-19{ }^{\circ} \mathrm{C}$ & $32.63 \mathrm{a}$ & $30.58 \mathrm{a}$ & $31.83 \mathrm{a}$ & $30.93 \mathrm{a}$ & $31.06 \mathrm{a}$ & 31.41 \\
$70^{\circ} \mathrm{C}$ & $32.36 \mathrm{a}$ & $31.56 \mathrm{a}$ & $30.76 \mathrm{a}$ & $31.68 \mathrm{a}$ & $31.15 \mathrm{a}$ & 31.50 \\
Rerata & 32.01 & 30.99 & 30.74 & 31.18 & 28.98 & $(+)$ \\
\hline
\end{tabular}

Keterangan: Angka yang diikuti huruf yang sama tidak menunjukkan beda nyata pada jenjang nyata $5 \%$ berdasarkan uji Duncan.

Tanda (+) : Menunjukkan ada interaksi antar perlakuan.

PE : Plastik Poly Ethylene

$\begin{array}{ll}\mathrm{PP} & \text { : Plastik Poly Propylene } \\ 27-29{ }^{\circ} \mathrm{C} & \text { : Suhu Ruang Kamar }\end{array}$

$17-19{ }^{\circ} \mathrm{C}$ : Suhu Ruang AC

$7{ }^{\circ} \mathrm{C} \quad$ : Suhu Ruang Cooler

Dari hasil analisis varian koefisiensi perkecambahan (CG) benih (Lampiran 2) diketahui bahwa koefisien perkecambahan benih kedelai setelah 4 bulan disimpan menunjukkan ada interaksi antara macam kemasan dengan suhu ruang simpan terhadap koefisien perkecmbahn seperti dapat dilihat pada tabel 5. Dari hasil pengujian kualitas benih sebelum disimpan, nilai koefisien perkecambahan yaitu (35.09) dan setelah empat bulan disimpan, nilai koefisiensi perkecambahan (CG) menunjukkan terjadinya penurunan. Dari data tabel 4 , dapat diketahui benih yang disimpan pada ruang kamar tanpa dikemas, nilai koefisien perkecambahan nyata paling rendah $(24,73)$ dibandingkan perlakuan yang lain. Hal ini disebabkan benih yang tidak dikemas akan dipengaruhi kondisi ruang simpan, pada ruang kamar suhu relatif tinggi sehingga laju respirasi benih meningkat sehingga cadangan makanan cepat menurun yang mengakibatkan koefisien perkecambahan benih setelah 4 bulan disimpan sangat rendah. Hal sebaliknya terjadi pada benih yang dikemas dengan plastik PE maupun PP divacum maupun tidak vacum yang disimpan pada ruang Cooler, AC maupun kamar, penurunan CG selama 4 bulan penyimpanan tidak terlalu besar. Hal ini dikarenakan kantong platik PE atau PP mampu berperan memodifikasi ruang kemas selama penyimpanan terhadap pengaruh dari luar seperti suhu dan kelembaban, sehingga kadar air dan suhu benih dapat dipertahankan, laju respirasi rendah, cadangan makanan dalam benih masih tinggi dan CG juga tinggi.

\section{Tinggi tanaman}

Tabel 6. Rerata Tinggi Tanaman umur 2 minggu (cm)

\begin{tabular}{|c|c|c|c|c|c|c|}
\hline \multirow{2}{*}{$\begin{array}{c}\text { Perlakuan } \\
\text { (R.Simpan) }\end{array}$} & \multicolumn{5}{|c|}{ Kemasan } & \multirow[b]{2}{*}{ Rerat } \\
\hline & $\begin{array}{c}\text { PE } \\
\text { Vacuum }\end{array}$ & $\begin{array}{l}\text { PE Non } \\
\text { Vacuum }\end{array}$ & $\begin{array}{c}\text { PP } \\
\text { Vacuum }\end{array}$ & $\begin{array}{l}\text { PP Non } \\
\text { Vacuum }\end{array}$ & $\begin{array}{c}\text { Tanpa } \\
\text { Pengemas }\end{array}$ & \\
\hline $27-29^{\circ} \mathrm{C}$ & $14.97 \mathrm{~b}$ & $10.16 \mathrm{bcd}$ & $0.00 \mathrm{e}$ & $17.01 \mathrm{~b}$ & $1.42 \mathrm{e}$ & 8.71 \\
\hline $17-19^{\circ} \mathrm{C}$ & 3.00 de & $15.17 \mathrm{~b}$ & $2.25 \mathrm{e}$ & 5.20 cde & 2.80 de & 5.69 \\
\hline $7^{\circ} \mathrm{C}$ & $17.84 \mathrm{~b}$ & $17.56 \mathrm{~b}$ & $11.93 b c$ & $14.51 \mathrm{~b}$ & $28.21 \mathrm{a}$ & 18.01 \\
\hline Rerata & 11.93 & 14.30 & 4.73 & 12.24 & 10.81 & $(+)$ \\
\hline $\begin{array}{ll}\text { Keterangan: } \\
\\
\text { Tanda }(+)\end{array}$ & $\begin{array}{l}\text { jang nyata } \\
\text { enunjukkan } \\
\text { astik Poly Et } \\
\text { astik Poly Pr } \\
\text { hu Ruang K } \\
\text { hu Ruang } \\
\text { hu Ruang }\end{array}$ & $\begin{array}{l}\text { ikuti huruf y } \\
5 \% \text { berdasar } \\
\text { ada interaks } \\
\text { ylene } \\
\text { pylene } \\
\text { amar } \\
\text { C } \\
\text { ooler }\end{array}$ & ntar perlak & menunju & $\mathrm{n}$ beda nya & \\
\hline
\end{tabular}


Dari hasil analisis varian tinggi bibit diketahui bahwa ada interaksi antara kemasan dan suhu ruang simpan. Dari tabel 6 terlihat bahwa penyimpanan benih kedelai selama 4 bulan pada ruang kamar dengan pengemas plastik PE vacuum maupun non vacuum dan plastik PP non vacuum tinggi tanamannya nyata lebih tinggi dibandingkan dengan pengemas plastik PP vacuum maupun tanpa pengemas. Penyimpanan pada ruang AC dengan pengemas plastik PE non vacuum tinggi tanamannya nyata lebih tinggi dibandingkan jenis pengemas lainnya maupun tidak dikemas. Sedangkan penyimpanan benih kedelai pada Cooler dengan pengemas PE maupun PP vacuum maupun non vacuum, tinggi tanamannya nyata lebih rendah dibandingkan tanpa pengemas, namun sama tingginya dengan pengemas terbaik yang disimpan pada ruang $\mathrm{AC}$ maupun ruang kamar.

\section{Berat kering}

Tabel 7. Rerata Berat Kering setelah disimpan selama 4 bulan (g)

\begin{tabular}{ccccccc}
\hline \multirow{2}{*}{$\begin{array}{c}\text { Perlakuan } \\
\text { (R.Simpan) }\end{array}$} & \multicolumn{5}{c}{ Kemasan } & \\
\cline { 2 - 5 } & $\begin{array}{c}\text { PE } \\
\text { Vacuum }\end{array}$ & $\begin{array}{c}\text { PE Non } \\
\text { Vacuum }\end{array}$ & $\begin{array}{c}\text { PP } \\
\text { Vacuum }\end{array}$ & $\begin{array}{c}\text { PP Non } \\
\text { Vacuum }\end{array}$ & $\begin{array}{c}\text { Tanpa } \\
\text { Pengemas }\end{array}$ & Rerata \\
\hline $27-29{ }^{\circ} \mathrm{C}$ & $1.14 \mathrm{~cd}$ & $1.27 \mathrm{~cd}$ & $0.00 \mathrm{e}$ & $1.99 \mathrm{bc}$ & $0.12 \mathrm{e}$ & 0.91 \\
$17-19{ }^{\circ} \mathrm{C}$ & $0.71 \mathrm{de}$ & $4.67 \mathrm{a}$ & $0.70 \mathrm{de}$ & $0.00 \mathrm{e}$ & $0.63 \mathrm{de}$ & 1.34 \\
$7{ }^{\circ} \mathrm{C}$ & $1.46 \mathrm{~cd}$ & $1.38 \mathrm{~cd}$ & $0.71 \mathrm{de}$ & $1.57 \mathrm{bcd}$ & $2.39 \mathrm{~b}$ & 1.50 \\
Rerata & 1.09 & 2.44 & 0.47 & 1.19 & 1.04 & $(+)$ \\
\hline
\end{tabular}

Keterangan: Angka yang diikuti huruf yang sama tidak menunjukkan beda nyata pada jenjang nyata $5 \%$ berdasarkan uji Duncan.

Tanda $(+)$ : Menunjukkan ada interaksi antar perlakuan.

PE : Plastik Poly Ethylene

$\begin{array}{ll}\mathrm{PP} & \text { : Plastik Poly Propylene } \\ 27-29^{\circ} \mathrm{C} & \text { : Suhu Ruang Kamar }\end{array}$

$17-19^{\circ} \mathrm{C}$ : Suhu Ruang AC

$7^{\circ} \mathrm{C} \quad$ : Suhu Ruang Cooler

Dari hasil analisis varian berat kering bibit diketahui bahwa ada interaksi antara kemasan dengan suhu ruang simpan. Pada tabel 7 dapat dilihat bahwa perlakuan penyimpanan benih kedelai dengan kemasan plastik Poly Ethylene tanpa vacuum di ruang $\mathrm{AC}$ menghasilkan berat kering bibit nyata lebih besar yaitu 4, 67 gram dibandingkan dengan perlakuan yang lain. Perlakuan penyimpanan benih kedelai dengan kemasan plastik PP non vacuum di ruang kamar menghasilkan berat kering bibit nyata lebih tinggi dibandigkan dengan jenis kemasan yang lain maupun tanpa dikemas. Sedangkan penyimpanerat kering bibit nyata lebih tinggi dibandingkan dengan dikemas kecuali dikemas dengan plastik PP non vacuum.

\section{SIMPULAN}

Dari hasil analisis dan pembahasan, maka dapat disimpulkan bahwa:

1. Penyimpanan benih kedelai pada suhu ruang kamar (27-29 ${ }^{\circ} \mathrm{C}$ dengan kemasan plastik Poly Ethylene (PE) dan Poly Propylene (PP) divacum maupun tanpa vacum dapat mempertahankan mutu benih kedelai selama 4 bulan disimpan.

2. Penyimpanan benih kedelai pada suhu ruang $\mathrm{AC}\left(17-19^{\circ} \mathrm{C}\right)$ dan suhu ruang Cooler $\left(7^{\circ} \mathrm{C}\right)$ dengan kemasan plastik PE atau PP divacum atau tanpa vacum, bahkan tidak dikemas dapat mempertahankan kualitas benih kedelai selama 4 bulan disimpan.

\section{DAFTAR PUSTAKA}

Anonim. 2011. Pemerintah Kaji Penurunan BM Kedelai. Diakses dari http://m.kompas.com/. Pada tanggal 01 April 2011. Danapriatna. 2004. Pengaruh Penyimpanan Tehadap Viabilitas Benih Kedelai. Diakses Dari http://Ditjenbun.Deptan.Go.Id/ Bbp2tpsur/Images/Stories/Perbenihan/Deteriorasi.Pdf.Pada Tanggal 20 Juni 2012.

Purwanti, S. 2004. Kajian Suhu Ruang Simpan Terhadap Kualitas Benih Kedelai Hitam Dan Kedelai Kuning. Diakses Dari http:// agrisci.ugm.ac.id/vol11 1/no4_kdlaihtm\&knng.pdf. Pada Tanggal 15 Maret 2011.

Pitojo, S. 2003. Benih Kedelai. Penerbit Kanisius. Yogyakarta.

Tatipata, A. Yudoyono, P., Purwantoro, A., dan W. Mangoendidjojo. 2004. Kajian Aspek Fisiologi Dan Biokomi Deteriorasi Benih Kedelai Dalam Penyimpanan. Jurnal IImu pertanian Vol.11 No.2.2004:76-87. Diakses pada tanggal 07 Februari 2007. 